\title{
The Indirect Impact of Surface Vegetation Improvement on the Climate Response of Sand-Dust Events in Northern China
}

\author{
Chaowei Zhou ${ }^{1,2}$, Xiaoming Feng ${ }^{1,2, *} \mathbb{C}$, Yichu Huang ${ }^{1,2}$, Xiaofeng Wang ${ }^{3}$ and Xinrong Zhang ${ }^{3}$ \\ 1 State Key Laboratory of Urban and Regional Ecology, Research Center for Eco-Environmental Sciences, \\ Chinese Academy of Sciences, Beijing 100085, China; cwzhou_st@rcees.ac.cn (C.Z.); \\ 171830009@smail.nju.edu.cn (Y.H.) \\ 2 University of Chinese Academy of Sciences, Beijing 100049, China \\ 3 School of Land Engineering, Chang'an University, Xi'an 710054, China; wangxf@chd.edu.cn (X.W.); \\ 2020027013@chd.edu.cn (X.Z.) \\ * Correspondence: fengxm@rcees.ac.cn; Tel.: +86-136-8350-2593
}

Citation: Zhou, C.; Feng, X.; Huang, Y.; Wang, X.; Zhang, X. The Indirect Impact of Surface Vegetation Improvement on the Climate Response of Sand-Dust Events in Northern China. Atmosphere 2021, 12, 339. https://doi.org/10.3390/ atmos12030339

Academic Editors: George Kallos and Zhenzhong Zeng

Received: 13 January 2021

Accepted: 1 March 2021

Published: 6 March 2021

Publisher's Note: MDPI stays neutral with regard to jurisdictional claims in published maps and institutional affiliations.

Copyright: (c) 2021 by the authors. Licensee MDPI, Basel, Switzerland. This article is an open access article distributed under the terms and conditions of the Creative Commons Attribution (CC BY) license (https:// creativecommons.org/licenses/by/ $4.0 /)$.

\begin{abstract}
Extensive ecosystem restoration is increasingly seen as an essential practice to mitigate climate change and protect the ecological environment. However, the indirect impact of surface vegetation improvement on the regional climate, such as the climate effect of sand-dust events reduction, has never been evaluated. Here, we estimated the feedback of temperature and precipitation on the change of sand-dust events, arising from the vegetation growth with ecological restoration, using a simple theoretical framework with a series of scenario simulations based on a regional climate model (RegCM). The results showed that revegetation reduced dust emissions, with a contribution rate of approximately $40.15 \%$. With the combined influence of ecological restoration and climate change, the cooling effect of sand-dust events strengthened with the increase in the intensity of sand-dust events, which is mainly caused by the strong absorption of shortwave radiation by the atmosphere. The response of precipitation was uncertain because of tropospheric circulation feedback and shortwave radiation absorption. Our results also indicate that changes in sand-dust events caused by vegetation restoration play important roles in shaping the future climate near the arid and semi-arid regions of northern China. The climatic effects of sand-dust events should be included in assessing ecological restoration impacts to promote sustainable development and enhance our understanding of climate change.
\end{abstract}

Keywords: ecological restoration; sand-dust events; climate response

\section{Introduction}

Changes in atmospheric dust loads have a major impact on the global climate system through geophysical processes or biochemical cycles [1-9]. Climate change, especially the change in surface wind speed, is one of the leading factors causing changes in atmospheric dust [10-13]. However, global assessment of sand and dust storms indicated that the human-induced hydrological changes, unsustainable land use, and land degradation had increased the major risk of wind erosion, thereby increasing the frequency and intensity of sand-dust events, especially in arid and semi-arid areas [12,14]. With the interactive influence of climate change and human activities on sand-dust events, the interaction between global climate and atmospheric dust remains highly uncertain $[9,12]$.

In response to a series of adverse health effects caused by sand-dust events, large-scale forestry planting, vegetation restoration, and reclamation have been widely used in areas affected by land desertification in arid and semi-arid areas that are plagued by sand and dust [15-19]. As the main source of sand and dust in East Asia, northern China is the most common and well-studied area in the world for controlling sand and dust and desertification through human measures. Since the late 1970s, numerous ecological restoration projects have been implemented, such as the Green Great Wall (GGW), the Grain to Green Program 
(GTGP), the Beijing-Tianjin Sand Source Control Project (BTSSCP), and the Returning Grazing Land to Grassland Project (RGLGP). Several studies have provided observational evidence that this type of ecological restoration measure can improve vegetation growth in northern China [20-22]. Approximately $214,000 \mathrm{~km}^{2}$ of degraded land was closed to prevent human disturbance, and more than $656,000 \mathrm{~km}^{2}$ of desertified and cultivated land was converted by planting shrubs and trees [23]. The effects of vegetation improvement, whether natural or artificial, on climate, such as temperature and precipitation, have been evaluated on multiple scales based on direct physical or biochemical processes [24-29]. However, the indirect climate response triggered by vegetation improvement, such as the reduction of dust emissions in arid and semi-arid areas, has not been studied.

Observation evidence based on remote sensing shows that the restoration of vegetation cover has significantly improved the frequency of sand-dust events in northern China [30-34]. The main mechanism of sand-dust event reduction by revegetation is that vegetation enhances surface coverage and reduces bare soil exposure [23]. The growth of vegetation significantly changes the physical and chemical properties of the soil. At the same time, the root system of growing vegetation fixes the soil. In the arid and semi-arid areas of China, vegetation is also used to form a vegetation barrier for sand fixation near the ground [35-37]. Studies have shown that windbreaks can reduce the wind speed by $20-50 \%$ in open areas, and the coverage can reach 15-20 times the height of the windbreaks [12,38]. A study in the Hexi Corridor of China showed that the windbreak system could reduce the wind speed by $70 \%$ and the sand flow speed by more than $80 \%$ [35]. Although vegetation has effectively reduced wind erosion, the impact of phenology and drought on vegetation-based ecological restoration implies uncertainty in the trend of sand-dust events under the cross-effects of climate change and large-scale human activities $[39,40]$. The improvement of land surface vegetation in arid and semi-arid areas contributed by ecological restoration has had unprecedented impacts on sand-dust events and regional climate, which are completely different from human-induced vegetation degradation and water shortages. Additionally, it is difficult to separate the climate effects of sand-dust event changes through site observations or remote sensing analysis. Under many uncertain factors, the response of regional climate to changes in the frequency and intensity of sand-dust events is still unknown.

This study provides insight into how sand-dust events changed due to revegetation and climate effects and how climate responded to them through variations in precipitation and temperature. With regional climate model $(\operatorname{Reg} C M)$ combined with the annual land cover data based on vegetation cover products, we conducted $3+2$ scenarios to explore (1) the impact of the ecological restoration project in northern China on the sand-dust event and its contribution rate and (2) the response of regional climate to changes in the frequency and intensity of sand-dust events under the cross-effects of climate change and large-scale human activities. Understanding the two-way interaction between dust and climate in the process of ecological restoration in arid and semi-arid regions will help to improve the understanding of global climate change, adaptation and mitigation strategies.

\section{Experiments}

\subsection{Study Area}

As one of the main sources of sand and dust in Central Asia and East Asia, northern China, a typical arid and semi-arid region, emits approximately $420-1120 \mathrm{Tg}$ of dust every year, accounting for $12 \%$ of the global dust emission and deposition [41-43]. Among them, the deserts, Gobi, dry lake beds, riverbeds, and river valleys in the Qaidam Basin, Tarim Basin, and Alxa Plateau are the main sources of sand and dust (Figure 1). Field surveys showed that the Tarim Basin and the Alxa Plateau are the most effective sources of sand and dust emissions in East Asia [44]. Although the Taklimakan Desert is the largest source of sand and dust in East Asia, its spring dust emissions account for $42 \%$ of the total sand and dust emissions in East Asia [45]. However, the amount of sand and dust transported in the spring and summer in the Gobi Desert accounted for 31-35\% of the total transport 
volume in East Asia, and this sand and dust has a more significant impact on metropolitan and populated areas on the west coast of the Pacific [31]. Under the influence of a long-term continental climate, the annual average precipitation is approximately $130 \mathrm{~mm}$, and the annual average evaporation is $800-3200 \mathrm{~mm}$. It is worth noting that since sand-dust events in the northern sand belt accounted for the majority $(60-75 \%)$ of events during this period, we focused on spring sand-dust events from March to May [31].

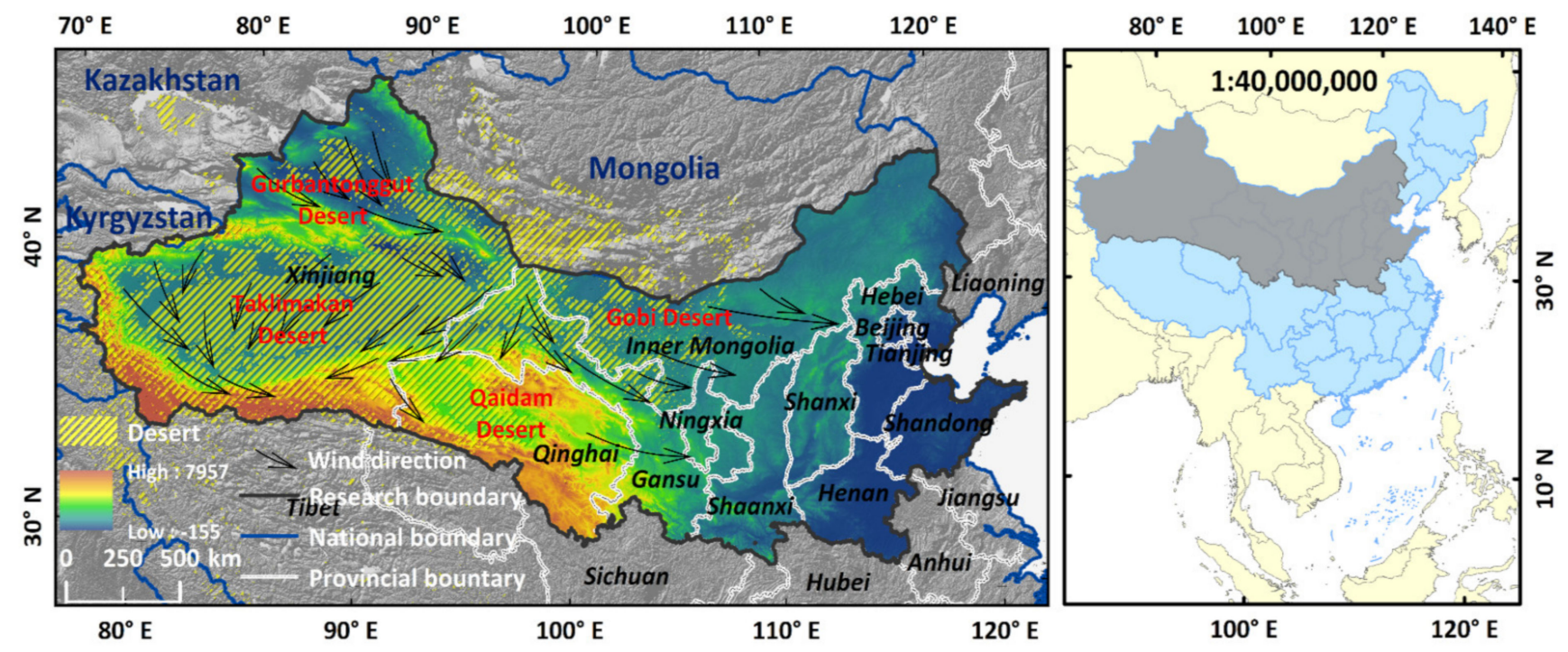

Figure 1. Location of northern China. There are four major dust sources in northern China: (1) the Taklimakan Desert, located in the central area of the Tarim Basin in southern Xinjiang, with an area of approximately $330,000 \mathrm{~km}^{2}$, which is the largest desert in China; (2) the Gobi Desert, located between Xilin Gol (Inner Mongolia) and Mongolia, with a total area of 1,300,000 $\mathrm{km}^{2}$; (3) the Gurbantunggut Desert, located in the center of the Junggar Basin (Xinjiang), with an area of approximately 48,800 km²; and (4) the Qaidam Desert, located in the Qaidam Basin (northeast of the Qinghai-Tibet Plateau), with an area of approximately $34,900 \mathrm{~km}^{2}$.

\subsection{Analysis Framework}

To explore the impacts of ecological restoration projects on sand-dust events and the response of temperature and precipitation caused by dust aerosols over north-eastern China, we proposed a research framework with two steps (Figure 2). First, we simulated sand-dust events using annual land cover data under the climatic background during 2000-2015. The variation in the three dust indicators caused by land cover change quantified the effects of vegetation growth on sand-dust events (Scenario A). Additionally, the practical situation of dust indicator change was used to evaluate the contribution rate of vegetation improvement to sand-dust events. Second, based on the simulation of sand-dust events during 2000-2015, we calculated the value of temperature and precipitation before and after sand-dust events by closing the chemical part in RegCM (Scenario B). The mechanism of how sand-dust events affect climatic effects was analyzed through the spatiotemporal features of the wind field and radiative forcing during 2000-2015.

\section{3. $\operatorname{Reg} C M$ Simulation}

Regional climate model version 4.7.0 (RegCM 4.7.0) was employed to simulate sanddust events. The model was developed at the National Center for Atmospheric Research (NCAR) and the Abdus Salam International Centre for Theoretical Physics (ICTP) [46-48]. The dynamic core is based on the hydrostatic model of the PSU/NCAR mesoscale MM5 model [49]. The model has been widely used and validated from process research and climate prediction to the simulation of aerosol and land-use change effects in East Asia [46-48]. Some studies in East Asia emphasized the model deviation of the system, which led to a large number of model improvements aimed at improving model performance [48,50,51]. 
The model has demonstrated excellent performance in reproducing near-surface concentrations, mass loadings, optical thicknesses, and spatiotemporal changes in dust aerosol emissions from major source areas [48].

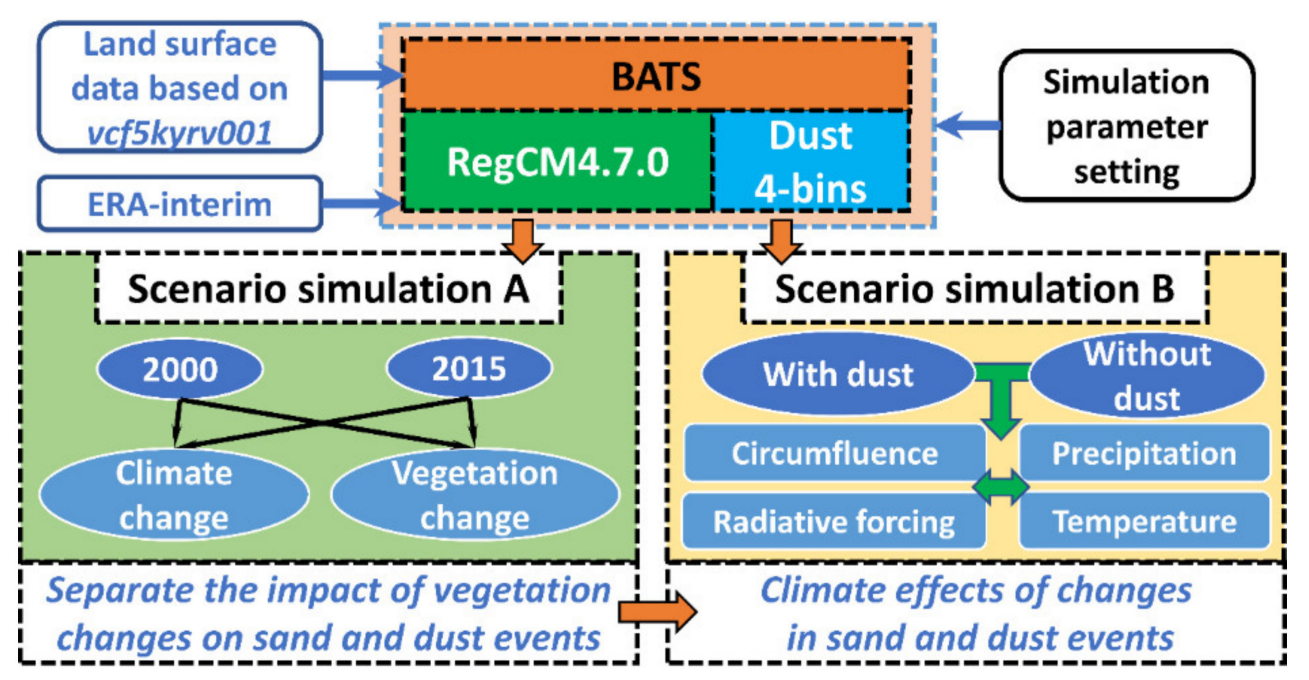

Figure 2. Analysis framework.

The RegCM-Dust coupling mode calculates the surface sanding, transmission, turbulent diffusion, deposition, and optical properties for several particle size categories for the temporal and spatial distribution of dust aerosols and regional climate effects $[46,47,52,53]$. The dust emission scheme includes three components [53-55]: (1) threshold friction velocity at the beginning of wind erosion; (2) horizontal and vertical dust emission fluxes; (3) the surface and soil-related factors influencing either the threshold friction velocity or the dust fluxes [56]. In this regard, dust is only emitted from the non-vegetated and snow-free parts of the grid box, which is calculated in the Biosphere-Atmosphere transfer scheme (BATS) land surface model. The size spectrum of the dust module is divided into 4 bins (fine: 0.01-1.00 $\mu \mathrm{m}$, accumulation: $1.00-2.50 \mu \mathrm{m}$, coarse: $2.50-5.00 \mu \mathrm{m}$, giant: $5.00-20.00 \mu \mathrm{m}$ ). The evolution of each bin is calculated by the prediction equation of the dry size of dust particles [53]. The dust transportation process is including the transport of decomposable scale wind, advection, turbulence, and deep convection, gravity sedimentation, wet and dry removal processes [52,53]. Wet deposition is divided into convective precipitation and large-scale precipitation to calculate separately $[57,58]$. The gravity settlement and dry sedimentation are calculated as the scheme of Zakey [53]. The specific calculation progress could be found in the research of Zhang et al. [56].

A new annual land cover data was produced through decision tree classification based on vegetation continuous field data products (vcf5kyrv001) to better characterize the impact of ecological restoration projects on land cover. These data were used as input for the BATS land surface model. Detailed information about the land surface dataset can be found in another article [23]. Additionally, ERA-interim global atmospheric reanalysis data were used as the atmospheric and land temperature global dataset for regional climate models [59-62]. Other physical schemes followed Su's research, which verified the effectiveness of RegCM with the proper model configuration in simulating the climate effect of sand-dust in East Asia [63]. The detailed model parameter settings are shown in Table 1. The simulation ran from February-May in 2000 and 2015, with the model pre-running in the first month and the formal simulation occurring during the last three months. Each sand-dust event was characterized by dust emission flux, dust extinction aerosol optical depth (DAOD), and burden simulated with RegCM. The usability analysis for simulating sand-dust events in northern China with the proper RegCM configuration is showed in Appendix A. 
Table 1. Parameter settings of RegCM.

\begin{tabular}{cc}
\hline Centre & $\mathbf{4 1}^{\circ} \mathbf{N}, \mathbf{9 9}^{\circ} \mathbf{E}$ \\
\hline Horizontal resolution & $60 \mathrm{~km}$ \\
Simulation area & $80 \times 36 \mathrm{cells}$ \\
Vertical sigma layers & 18 \\
Pressure at the top level & $60 \mathrm{hPa}$ \\
Timestep & $120 \mathrm{~s}$ \\
Timestep for the land surface & $12 \mathrm{~h}$ \\
Timestep for the radiation & $30 \mathrm{~min}$ \\
Timestep for the chemical models & $600 \mathrm{~s}$ \\
Lateral Boundary conditions scheme & RW PBL scheme \\
Boundary layer scheme & Relaxation, exponential technique scheme \\
Cumulus cloud parameterization scheme & Uh Prid convection scheme (the Grell scheme was used over \\
Moisture scheme & land and the Emanuel scheme was used over the ocean) \\
Ocean Flux scheme & Explicit moisture scheme \\
Zeng scheme
\end{tabular}

\subsection{Scenario Setting}

To separate the impact of vegetation improvement and climate change on sand-dust events, we established three scenarios through control experiments based on ground cover and climate background in 2000 and 2015 (Table 2). In scenario A1, the difference in the simulated dust indicators represents the actual change in sand-dust events from 2000-2015. In scenario A2, the climate background is kept unchanged, and only the surface cover is changed during the dust simulation process. The difference in simulated sand and dust represents the impact of surface vegetation changes on sand-dust events. Similarly, the difference in simulated sand and dust in the A3 scenario represents the impact of climate change on sand-dust events. Then, the contribution rate of vegetation improvement and climate change to the change in sand-dust events can be calculated by the ratio of the change in sand-dust events in the $\mathrm{A} 2$ and $\mathrm{A} 3$ scenarios to those in the $\mathrm{A} 1$ scenario, respectively.

Table 2. Scenarios used in the RegCM analysis.

\begin{tabular}{cll}
\hline Scenario & \multicolumn{1}{c}{ Scenario Context (Independent Variable) } & \multicolumn{1}{c}{ Dependent Variable } \\
\hline A & A1: Vegetation improvement and climate change & \\
A2: Vegetation improvement & Dust emission flux, DAOD, and burden \\
B & A3: Climate change & \\
$(2000-2015)$ & B1: Dust aerosols & Temperature and vegetation \\
\hline
\end{tabular}

Based on the dust simulation scenario during 2000-2015 (B1), a scenario without dust simulation was added (B2). By comparing the changes in basic meteorological elements, such as temperature and precipitation, between scenarios B1 and B2, the impact of changes in sand-dust events on regional climate was quantified. Changes in radiative forcing and circulation were introduced to further explain the process of climate feedback.

\section{Results}

\subsection{Effects of Ecological Restoration Projects on Sand-Dust Events in Northern China}

The impact of vegetation improvement and climate change on sand-dust events in northern China was separated by scenario simulations that controlled a single variable (climate or land cover). With the combined influence of ecological restoration and climate change, the dust emission flux decreased by $59.70 \mathrm{~g} / \mathrm{m}^{2} \cdot \mathrm{s}(+3.90 \%)$ during spring 2000-2015, which made the DAOD and burden increase by $0.0062(+2.41 \%)$ and $15.66 \mathrm{~g} / \mathrm{m}^{2} \cdot \mathrm{s}$ $(+1.90 \%)$, respectively (Figure 3a). The observations based on remote sensing showed that 
the vegetation cover in the area increased by $6.76 \%$ during this period. At the same time, the spring-averaged near-surface temperature, precipitation, and soil moisture in northern China increased by $0.065 \%, 43.93 \%$, and $9.71 \%$, respectively, with the influence of regional climate change. However, when the impact of climate change was removed, we found that the improvement in vegetation reduced sand-dust events in the spring in northern China, which was contrary to the actual trend (Figure 3b). The dust emission flux, DAOD, and burden decreased by $64.57 \mathrm{~g} / \mathrm{m}^{2} \cdot \mathrm{s}(-8.32 \%), 0.016(-6.03 \%)$, and $61.96 \mathrm{~g} / \mathrm{m}^{2} \cdot \mathrm{s}(-7.20 \%)$, respectively, during spring 2000-2015. The impact of vegetation improvement on sanddust events was also verified in scenario A3, in which the dust emission flux, DAOD, and burden increased by $34.87 \mathrm{~g} / \mathrm{m}^{2} \cdot \mathrm{s}(+4.82 \%), 0.022(+8.99 \%)$, and $77.61 \mathrm{~g} / \mathrm{m}^{2} \cdot \mathrm{s}(+9.81 \%)$, respectively (Figure 3c). With the single influence of climate change, the increase in sand-dust events far exceeded the actual increase in northern China during spring 2000-2015. The scenario simulation results showed that the contribution rate of vegetation improvement to spring dust changes in northern China reached an astonishing value of $40.15 \%$.

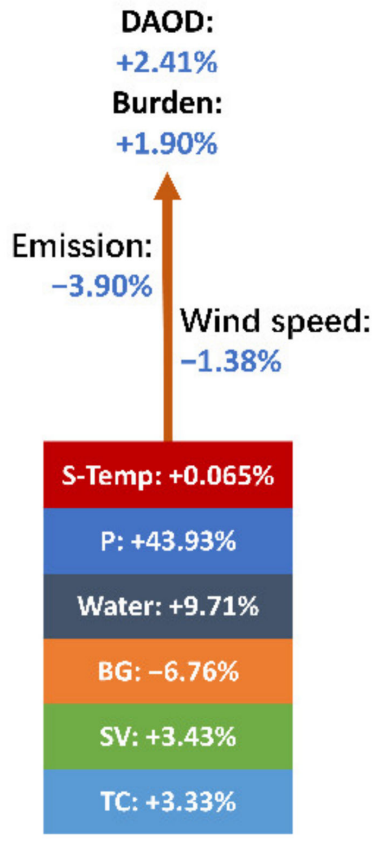

a

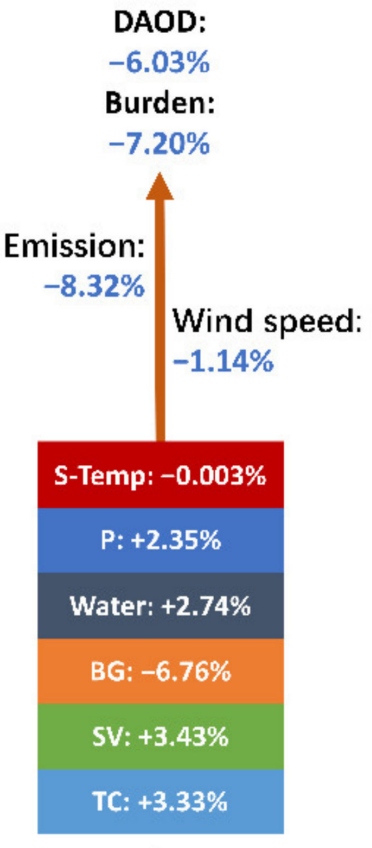

b

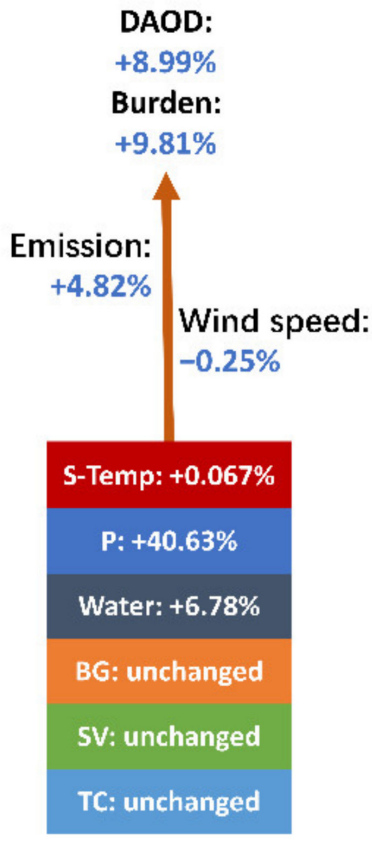

c

Figure 3. The three scenarios of spring sand-dust event variation during the period of 2000-2015 over northern China based on AVHRR-BATS land cover data. (a) Scenario A1: The sand-dust events are affected by climate change and vegetation cover changes; (b) scenario A2: The sand-dust events are affected only by vegetation cover changes; (c) scenario A3: The sand-dust events are affected only by climate change. S-Temp: Near-surface temperature from RegCM simulation; P: Precipitation from RegCM simulation; BG, SV, and TC: Bare ground, short vegetation, and tree canopy, respectively, derived from vcf5kyrv001 data products.

\subsection{Feedback of Dust Climate Effects on Temperature and Precipitation}

We simulated the trend of sand-dust events driven by the interaction of vegetation improvement and climate change in northern China during spring 2000-2015 and then combined it with the scenario without dust simulation to estimate the impact of sand-dust events on the regional climate. The scenario simulation results showed that the sand-dust events in northern China during spring 2000-2015 decreased the regional temperature $\left(-0.28{ }^{\circ} \mathrm{K}\right)$ (Figure 4$)$, which was driven by radiative forcing caused by the change in sand-dust events. As shown in Figure A3, the net radiative forcing at the top of the atmosphere and the atmospheric net radiative forcing were both increasing $\left(0.044 \mathrm{~W} / \mathrm{m}^{2} \cdot \mathrm{a}\right.$ and $0.271 \mathrm{~W} / \mathrm{m}^{2}$.a respectively) with the increase in the fluctuation of dust events in 
northern China. The positive trend of atmospheric top radiative forcing implied a greater proportion of shortwave absorption by dust. The possible reason is that the increase in vegetation has reduced the emissions of dust in the atmosphere $(-8.32 \%)$ though sand-dust events have increased year by year. Among them, vegetation was more effective in reducing the dust particles with large size, which reduced the longwave radiation scattering in the increasing radiative forcing of dust. However, due to the annual increase in atmospheric dust, the cooling effect on surface temperature caused by the spring sand-dust event in northern China has gradually enhanced $\left(-0.004^{\circ} \mathrm{K} / \mathrm{a}\right)$.

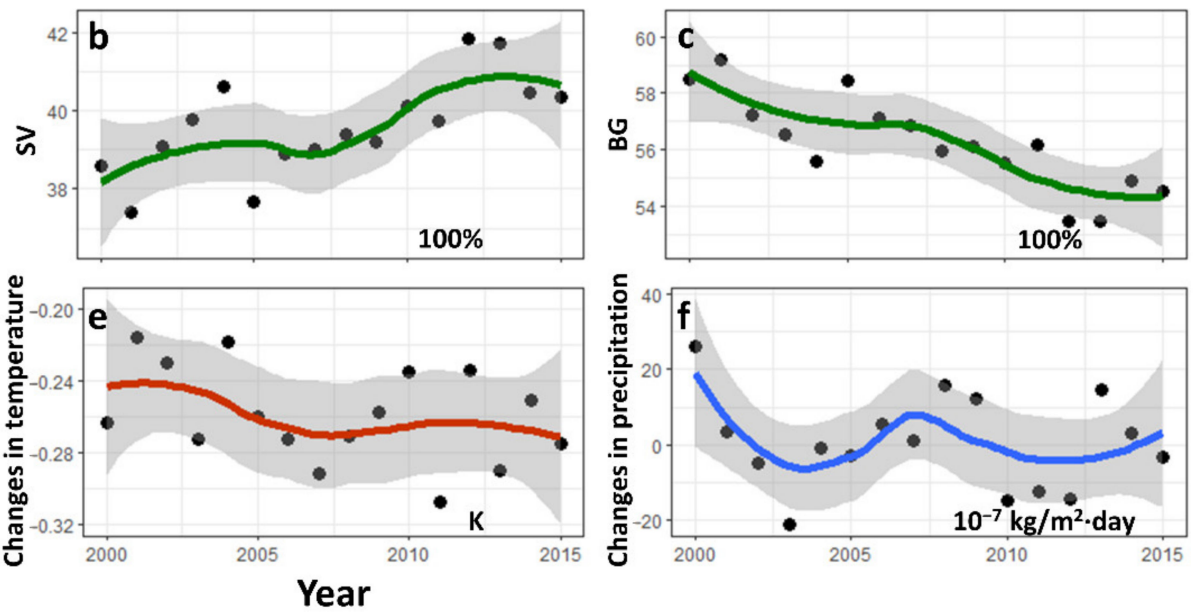

Figure 4. Temporal variance in vegetation, DAOD, temperature difference, and precipitation difference under the interplay of climate change and revegetation during 2000-2015 in northern China. (a) Tree canopy; (b) short vegetation; (c) bare ground; (d) change in spring-averaged DAOD; (e) temperature difference between scenarios B1 and B2: Dust-induced spring average temperature and scenario without dust influence; (f) precipitation difference between scenarios B1 and B2: Dust-induced spring average precipitation and scenario without dust influence. The trends of land cover, DAOD, temperature change, and precipitation change were respectively fitted with green, orange, red, and blue curves by the locally weighted regression (loess) method. The gray area represents the confidence interval of curve fitting.

In the spatial domain, the temperature trend was mostly negative in northern China, but positive around dust source areas (for example, west of the Taklimakan Desert and northeast of the Gobi Desert) (Figure 5a-c). The results of the scenario simulation showed that the net radiative forcing at the top of the atmosphere and the atmospheric net radiative forcing were both positive $\left(2.043 \mathrm{~W} / \mathrm{m}^{2}\right.$. a and $12.408 \mathrm{~W} / \mathrm{m}^{2} \cdot$ a respectively) (Figure A4c,f and Table A1). The absorption of shortwave radiation $\left(0.974 \mathrm{~W} / \mathrm{m}^{2} \cdot \mathrm{a}\right.$ and $18.742 \mathrm{~W} / \mathrm{m}^{2} \cdot \mathrm{a}$ respectively) was much stronger than the reflection of longwave radiation $\left(1.069 \mathrm{~W} / \mathrm{m}^{2} \cdot \mathrm{a}\right.$ and $-6.334 \mathrm{~W} / \mathrm{m}^{2}$. a respectively) by the atmosphere (Figure A4a-c,e and Table A1), which was mainly caused by the concentration of sand and dust. The accumulation of dust in the dust source area absorbs a large amount of solar shortwave radiation, which raised the average surface temperature above $0.6{ }^{\circ} \mathrm{K}$ (Figure 5c). The main area with a significant cooling effect was concentrated in the radiation area of sand and dust. As the concentration of sand and dust decreased, the absorption of shortwave radiation in the atmosphere weakened (Figure A4a). The net radiative forcing at the top of the atmosphere in these areas was negative, making the cooling effect more significant (Figure A4c). In addition, the increase in evapotranspiration and latent heat flux transfer and the decrease in surface albedo caused by revegetation made the cooling effect of sand-dust events on the groundatmosphere system more obvious (for example, in the eastern Gobi Desert). 

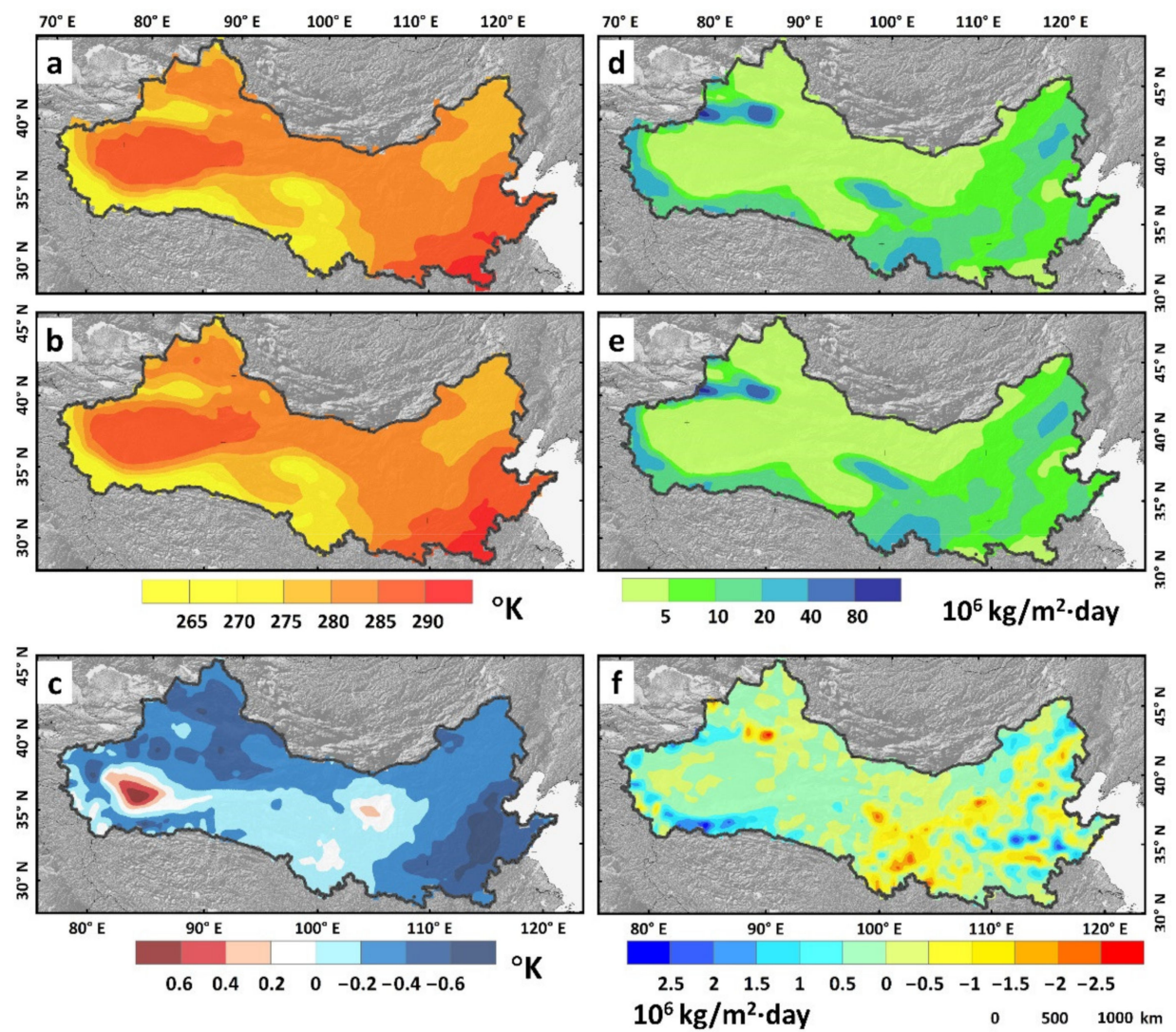

Figure 5. The variation in surface temperature and precipitation induced by spring dust aerosols during 2000-2015 in northern China. (a) Scenario B1: Surface temperature under the effect of dust aerosols; (b) scenario B2: Surface temperature without considering dust aerosols; (c) the difference between B1 and B2, indicating the change in temperature caused by dust aerosols; (d) scenario B1: Precipitation under the effect of dust aerosols; (e) scenario B2: Precipitation without considering dust aerosols; (f) the difference between B1 and B2, indicating the change in precipitation caused by dust aerosols.

Additionally, our results showed a significant positive correlation between spring precipitation and sand-dust events in northern China $(\mathrm{r}=0.501, p=0.048)$. However, only when the dust event increases to a certain extent will it increase the regional precipitation. In the years when the intensity of sand and dust events was relatively small, it caused a decrease in precipitation (e.g., $-2 \times 10^{-7} \mathrm{~kg} / \mathrm{m}^{2}$.day in 2003). Furthermore, sand-dust events lead to a decrease in precipitation in the main dust source areas and their radiation regions. The main reason for this pattern is that sand-dust events have enhanced the circulation of the late winter monsoon, especially in the lower and middle troposphere, which results in a significant decrease in the water vapor mixing ratio in the middle and lower troposphere (Figure A2), accompanied by a sinking movement. For example, in northwestern China and Central China, where dust cover spread, precipitation decreased by more than $12.53 \%$ $\left(0.5 \times 10^{-6} \mathrm{~kg} / \mathrm{m}^{2}\right.$.day $)$. In addition, sand-dust events also caused the ground to cool down, which was conducive to improving atmospheric stability and reducing surface evaporation. The reduction in humidity inhibits the formation of clouds accompanied by the generation of downdrafts, leading to a reduction in precipitation. However, with the influence of monsoon changes, the impact of sand-dust events on the circulation weakened. With the warm and humid summer monsoon, the dust particles at the end of the dust emission and transmission can act as condensation nuclei of raindrops and condense the water vapor in the cloud at a higher temperature, thereby increasing precipitation. At the same time, it can induce an upward movement in the lower troposphere in the relevant 
affected area, offsetting the decrease in humidity caused by the sand-dust event; thus, precipitation can increase in the coastal areas of Central and North China.

\section{Discussion and Conclusions}

The ecological restoration project in northern China continues to expand at an average annual rate of approximately $3.33 \times 10^{4} \mathrm{~km}^{2}$. However, the impacts of large-scale vegetation restoration on the natural ecosystem, environmental resources, and regional climate have not been fully assessed. Case studies have shown that the expected ecological benefits are usually accompanied by other impacts, such as the exacerbation of drought events, causing conflicts in water resources and affecting regional precipitation with large-scale vegetation restoration in arid and semi-arid regions [27,39,64]. These uncertain effects indicate that the feedback of vegetation restoration on the climate, including the subsequent indirect impacts of sand and dust, should be thoroughly evaluated when planning to improve regional sand-dust events.

Our analysis determines the contribution rate of human-induced improvement in vegetation cover to the change in sand-dust events in northern China. The results show that vegetation improvement has eased the increasing trend of sand-dust events mainly caused by climate change in northern China by reducing dust emissions. The fact that vegetation restoration in the dust sources of arid and semi-arid areas has improved to reduce sanddust events has been confirmed by other studies [23,65-67]. It is worth noting that the contribution rate of vegetation improvement to the change in sand-dust events is almost $40 \%$, which is greater than the values reported in other cases [23,66]. The main reason may be that our research started since the ecological restoration, and the study area covered the Taklimakan Desert, which emits more dust. Additionally, we used control experiments based on scenario simulations in 2000 and 2015 to represent the changes in sand-dust events throughout the study period. Among them, 2000 was a year when sand-dust events were relatively frequent, and 2015 was a year when relatively few sand-dust events occurred (2000: 9.20; 2015: 4.40; 2000-2015 average: 6.03). It indicated the contribution rate calculated based on the 2000 and 2015 scenarios was uncertain. However, the average DAOD in the spring of 2000 and 2015 was higher than the average of 2000-2015 (2000: 0.26; 2015: 0.27; 2000-2015 average: 0.25 ), which showed that the scenario analysis based on 2000 and 2015 is representative in the years of high dust load. Therefore, with more ecological restoration projects implemented, the indirect response of climate to vegetation improvement through sand-dust events cannot be ignored.

This paper provides the first explicit estimation of the dust-climate feedback due to vegetation improvement caused by ecological restorations. Through the scenario simulation with the dust mode as an independent variable, the direct influence of vegetation on the regional climate is completely separated. The results showed that sand and dust had a cooling effect on the near-surface land and increased regional precipitation from 2000-2015. As other studies have shown, this series of climatic effects begin with the difference in radiative forcing produced by sand-dust events and affects precipitation through temperature and circulation fields [63]. The signal and intensity of the dust climate feedback vary greatly within the region, and the dust climate effect in the dust source area and the dust radiation area is more significant. With the combined influence of ecological restoration and climate change, sand-dust events in northern China have increased. In this process, the cooling effect of sand-dust events was strengthened with the increase in the net radiative forcing at the top of the atmosphere, which was mainly caused by the increased absorption of solar longwave radiation and shortwave radiation by sand and dust. Due to the refinement of the dust particle size distribution and the decrease in surface reflectivity during long-distance transportation, the scattering of longwave radiation and the absorption of shortwave radiation were weakened while the scattering of shortwave radiation and the absorption of longwave radiation was enhanced. Therefore, in the process of sand and dust transportation, the impact of sand and dust on the surface temperature presents a gradual transition from warming interaction to cooling 
interaction. However, the response of precipitation to sand-dust events was uncertain. Our research showed that under the combined effects of vegetation improvement and climate change, the impact of sand dust on regional precipitation is positively correlated with sand dust events significantly. When the intensity of sand-dust events decreased to a low value, sand-dust events reduced the amount of regional precipitation; when the dust event increased to a high value, sand-dust events increased the amount of regional precipitation. The possible reason is the enhancement of surface evapotranspiration caused by the strong absorption of shortwave radiation, which showed in the analysis results of radiative forcing [68]. The replenishment of water still leads to an increase in precipitation with the enhanced tropospheric circulation. Additionally, the complex interaction among the strength of the monsoon, the overall trend of climate change, and the sand-dust event process of the year may also be the corresponding reasons for the fluctuation in precipitation, which still needs further analysis.

The interaction between global dust load and global climate change has been proven highly uncertain because it is difficult to separate dust from other aerosol loads. Through the simulation based on the RegCM scenario, this study quantified the impact of the changes in sand-dust events on the regional climate under the combined effects of surface vegetation improvement and climate change. Although a series of rigorous controlledvariable experiments were adopted, there may still be great uncertainties in the interaction between sand-dust events and climate change. One of the reasons for this is that the impact of atmospheric dust on climate depends on a wide range of Earth system processes, and our modeling is limited to a regional scale within a discontinuous time range [69-71]. During the simulation of sand-dust events, some large-scale physical feedback processes have not been fully simulated, such as ocean-atmosphere interaction and the influence of the Tibetan Plateau on the climate of northern China. The trend of sea surface temperature plays an important role in the process of interaction within vegetation, dust events, and precipitation. The Tibetan Plateau affects the climate in northern China through the chained impacts of interaction between westerlies and the Indian monsoon [72]. These limitations make it different from the results of the global long-term continuous simulation of sand-dust climate effects [68]. At the same time, the simulation of the many indirect effects of sand and dust on the climate, which could potentially be of substantially greater magnitude than the direct sand-dust climate effect, were not considered in climate models including RegCM [73-75]. Additionally, the spatial resolution of this study was $60 \mathrm{~km}$, which limits the accuracy of the simulated sand-dust events and their climate effects (including temperature and precipitation). The study of dust events and their climatic effects needs to be simulated at higher spatial resolution and more extensive spatial range to further evaluate and improve at a local scale [63]. Therefore, further research is still needed to reduce the uncertainty of sand-dust event simulations.

Although there are still uncertainties in these results, this study indicates that changes in sand-dust events caused by vegetation restoration will play an important role in shaping the future climate near the arid and semi-arid regions of northern China. The fragile ecosystems in arid and semi-arid regions are extremely sensitive to changes in precipitation and temperature, which in turn will form new feedbacks that will have a deeper impact on the regional climate and ecosystems [76,77]. We suggest comprehensive optimization of ecological restoration benefits, costs, and resource consumption in key ecological restoration areas as an alternative to expanding ecological restoration projects. On the one hand, large-scale land cover changes significantly impact the regional climate, environment, and ecosystem [24-29]. On the other hand, the feedback mechanism for some of these impacts is still unclear, which increases the uncertainty of the additional impact of ecological restoration projects on the regional environment [9]. In addition, in the process of combating desertification and global climate change through ecological restoration projects, the climatic effects of sand-dust events should be included in the assessment of ecological restoration impacts to promote sustainable development and help us further understand climate change. 
Author Contributions: Designed the research X.F.; conducted the data analysis and interpretation C.Z. and X.F.; drafted the manuscript with significant contributions to the writing from all co-authors Y.H. and C.Z.; reviewed the manuscript X.F., X.W., and X.Z. All authors commented on and approved the final manuscript. All authors have read and agreed to the published version of the manuscript.

Funding: This research was funded by the National Natural Science Foundation of China, grant numbers 41991233; the Chinese Academy of Sciences, grant number QYZDY-SSW-DQC025; and the National Key Research and Development Program of China, grant number 2017YFA0604700.

Institutional Review Board Statement: Not applicable.

Informed Consent Statement: Not applicable.

Data Availability Statement: Not applicable.

Conflicts of Interest: The authors declare no conflict of interest.

\section{Appendix A}

\section{Appendix A.1 Data Sources}

We used vegetation continuous field (VCF) data products (vcf5kyrv001) to analyze the changes in vegetation cover. Additionally, VCF data were used as a key indicator in the production process of annual land cover data in RegCM [23]. This product is mainly compiled by the Advanced Very High Resolution Radiometer (AVHRR) and can quantify land-cover change on a regional or global scale compared to land-use data based on specific classification systems. Each pixel is characterized by the coverage rate of the tree canopy (TC), short vegetation (SV), and bare ground (BG), where TC is the proportion of ground covered by the vertical projection of the tree canopy, SV is the proportion of ground covered by vegetation other than trees (including shrubs and herbaceous vegetation), and BG is the proportion of ground not covered by vegetation. Probability sample analysis based on ultrahigh-resolution remote sensing imagery indicates that the direct impact of human activities in northern China exceeded $75 \%$, which could be attributed to extensive ecological restoration projects. In addition, the data accuracy is greater than $90 \%$ (verified against USGS and Landsat vegetation continuous field products) [78].

\section{Appendix A.2 The Usability Analysis for Simulating Sand-Dust Events in Northern China with $\operatorname{Reg} C M$}

MERRA2 dust aerosol reanalysis data were used to verify the dust simulation with RegCM. The aerosol data in MERRA2 is simulated by the radiation coupling version of the Goddard Chemistry, Aerosol, Radiation, and Transport model (GOCART), which handles the source, absorption, and chemical composition of the tracer of 15 external mixed aerosol mass mixtures [54]. Among them, the emission of dust (5 segments of the non-overlapping particle size range) is related to wind speed, which refers to the location map of potential dust sources and is parameterized according to the research of Marticorena and Bergametti (1995) [79]. After the simulation, MERRA2 aerosol analysis uses the Goddard Aerosol Assimilation System (GAAS) to assimilate data with remote sensing products and ground station observation data to improve data accuracy further. The comparison and verification results of MERRA2 dust aerosol products with Barbados $\left(13.17^{\circ} \mathrm{N}, 59.53^{\circ} \mathrm{W}\right)$ and Miami University $\left(25.75^{\circ} \mathrm{N}, 80.25^{\circ} \mathrm{W}\right)$ site long-term observation data are very satisfactory (R2 = 0.692, 0.775) (https://gmao.gsfc.nasa.gov/pubs/docs/Randles887.pdf, accessed on 15 March 2017). During the verification process in northern China, although MERRA2 dust aerosol products cannot fully simulate the peak of aerosol indicators, they can generally simulate the temporal and spatial trends of aerosols well [80].

We have constructed 4 different land cover scenarios here to analyze the impact of different land cover data and land surface patterns on the RegCM simulation of sand-dust events in northern China during the spring of 2000-2015: S1: Dust simulation based on our decision tree classification results with VCF data products (vcf5kyrv001), in which the land surface model is BATS; S2: Dust simulation based on European Space Agency 
Climate Change Initiative Land Cover (ESA CCI-LC) data, in which the land surface model is BATS; S3: Dust simulation based on GLCC data, in which the land surface model is BATS; S4: Dust simulation based on plant functional types (PTFs) data, in which the land surface model is Community Land Model (CLM) 4.5.

The results showed that the simulated DAOD had a positive deviation from MERRA2 DAOD in most areas of northern China, especially in the Taklimakan Desert, the Gobi Desert, and the radiation area (Figure A1). The positive deviation was large, which can reach more than 0.3 . There was a certain negative deviation in the wide-area surrounding the Taklimakan Desert, especially in the southern high-altitude areas. The negative deviation was as high as -0.2 or more. Additionally, the DAOD simulation was between -0.1 and 0.1 in other areas. The main reasons for deviation from MERRA2 DAOD are: (1) The MERRA2 dust aerosol product cannot fully simulate the peak of the sanddust event, which made its DAOD smaller than the actual value; (2) The calculation of the dust emission process was different. Among them, the particle size of the dust model of RegCM4.7.0 was larger than that of MERRA2 (RegCM: 0.01-20.0 $\mu$ m; MERRA2: about $0.1-10 \mu \mathrm{m}$ ), and the calculated spectral ranges of the particles were inconsistent (RegCM: visible light range 0.35-0.64 $\mu \mathrm{m}$ DAOD; MERRA2: $550 \mathrm{~nm}(0.55 \mu \mathrm{m})$ DAOD). Another possible reason is the inconsistency of the data space range: the space range of RegCM simulation is limited, and the dust source outside the simulation range was not considered, which made the DAOD of the two spatially different. These reasons led to a significant deviation between DAOD and MERRA2 DAOD data in the source area of sand. The average correlation coefficient between the simulated spring average DAOD and MERRA2 DAOD data under the four scenarios reached $0.769(p<0.001)$. It indicated that the RegCM could better simulate the spatial distribution of dust and its emission and transmission process in northern China in spring.
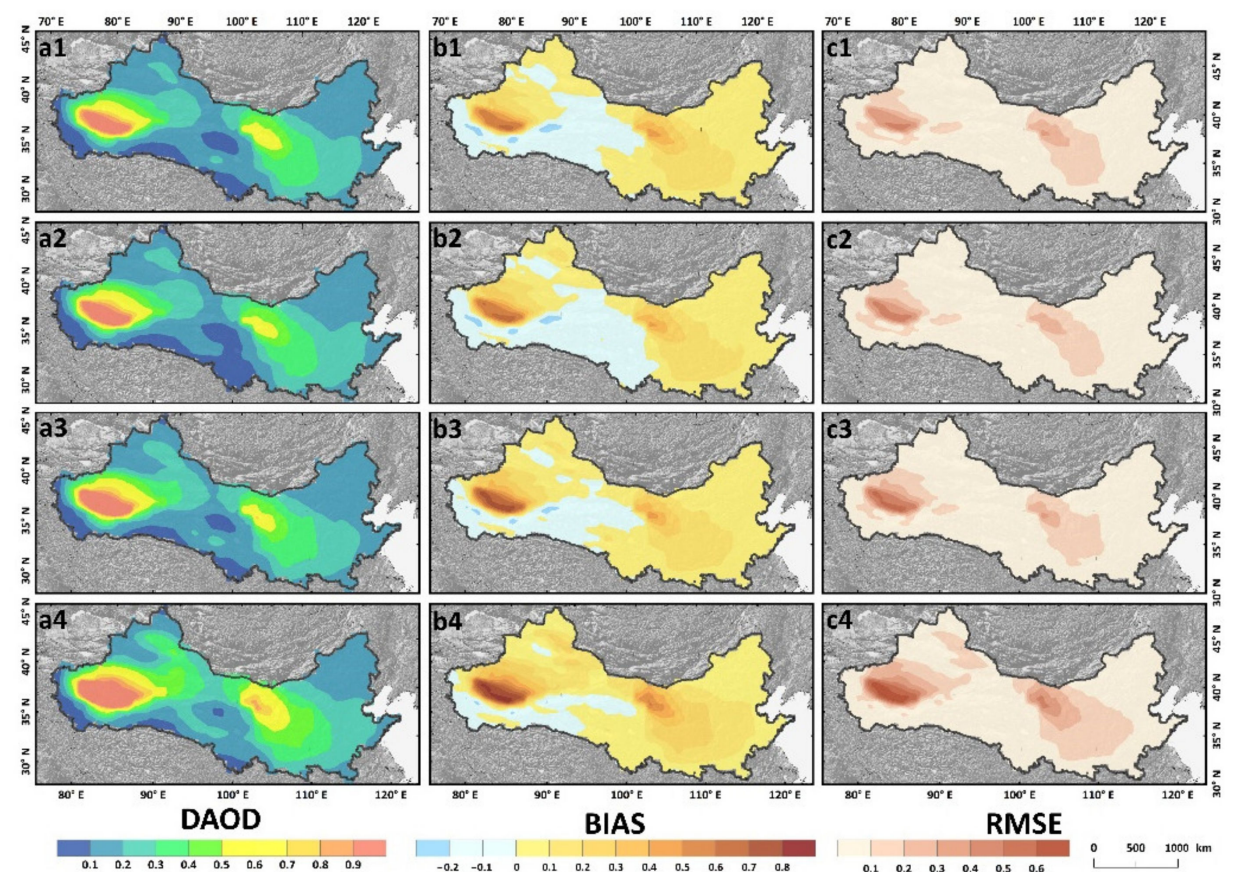

Figure A1. Spring DAOD, simulation bias, and RMSE in northern China from 2000-2015. (a) DAOD; (b) simulation bias; (c) simulation RMSE; 1. Dust simulation input based on our decision tree classification results with VCF data products (vcf5kyrv001), in which the land surface model is BATS; 2. Dust simulation based on ESA CCI-LC data, in which the land surface model is BATS; 3. Dust simulation based on GLCC data, in which the land surface model is BATS; 4. Dust simulation based on PTFs data, in which the land surface model is CLM4.5. 
The results of trend analysis showed the average DAOD in spring in northern China ranges from 0.16-0.21, reaching a high level from 2006-2009 (>0.20). It began to decrease year by year after 2013, and the minimum was reduced to 0.16 . The DAOD by RegCM was generally larger than the DAOD value of MERRA2. As shown in Figure A2b-d, March was the largest month, followed by April, and May was the smallest. In addition, the interannual fluctuations of DAOD simulated by RegCM were stronger, mainly because the sand emission model in the RegCM simulation process took into account the additional 10-20 $\mu \mathrm{m}$ dust compared with MERRA2. It caused additional dust emissions and transmission in the relevant years, making the dust events showed greater fluctuations on the annual scale. Moreover, RegCM only considered the discharge and transportation of local dust sources. The dust outside the study area and the dust drifting along with the westerly wind were not considered, which caused the difference in inter-annual fluctuations to a certain extent. At the same time, the simulation results showed that DAOD increased from 2012-2015, which was consistent with related observation records around the Taklimakan Desert (such as Qinghai). For MERRA2 reanalysis data, the DAOD showed a decreasing trend year by year, which may be affected by the overall trend of global dust, and may also be affected by the overall trend of dust aerosol. Research had shown that the simulated value of the MERRA2 aerosol component is relatively small [80], and the calculation of the aerosol peak is weak. The main reason is that the dust aerosol is separated by total aerosol assimilation. Even so, RegCM simulation captured inter-annual fluctuation, such as the strong sand-dust events from 2000-2002, the strong sand-dust events from 2006-2007, and the reduction of sand-dust events after 2013. It indicated that the trend of DAOD in RegCM simulation and MERRA2 data is similar. In general, the comparison results showed that the DAOD simulated by RegCM with the physical schemes in our research is available in northern China.
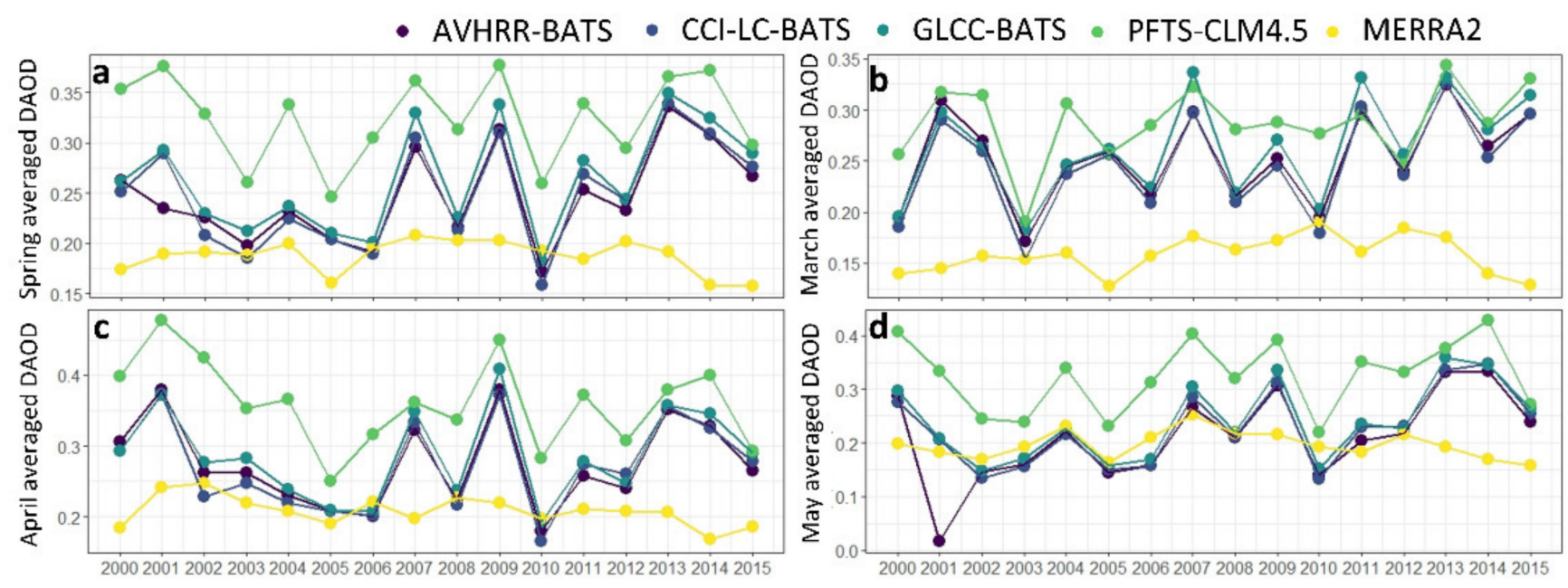

Figure A2. The trend of DAOD in spring in northern China from 2000-2015. (a) Spring averaged DAOD; (b) March averaged DAOD; (c) April averaged DAOD; (d) May averaged DAOD. (Lines 350-353 in the revised manuscript.). 

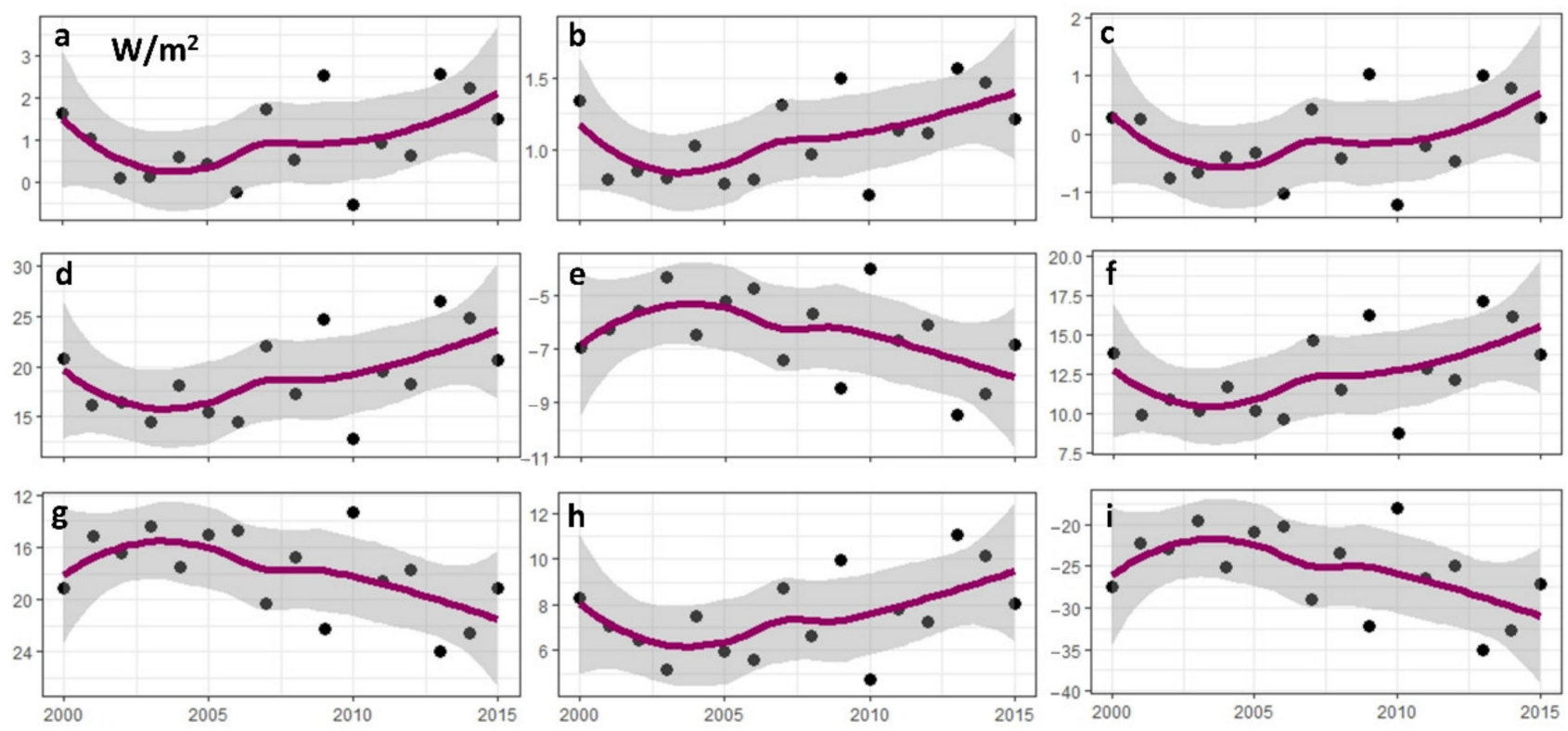

Figure A3. Trends of dust aerosol radiative forcing in spring. (a) Shortwave radiative forcing at the top of the atmosphere; (b) longwave radiative forcing at the top of the atmosphere; (c) net radiative forcing at the top of the atmosphere; (d) shortwave radiative forcing in the atmosphere; (e) longwave radiative forcing in the atmosphere; (f) atmospheric net radiative forcing; (g) surface shortwave radiative forcing; (h) surface longwave radiative forcing; (i) surface net radiative forcing.
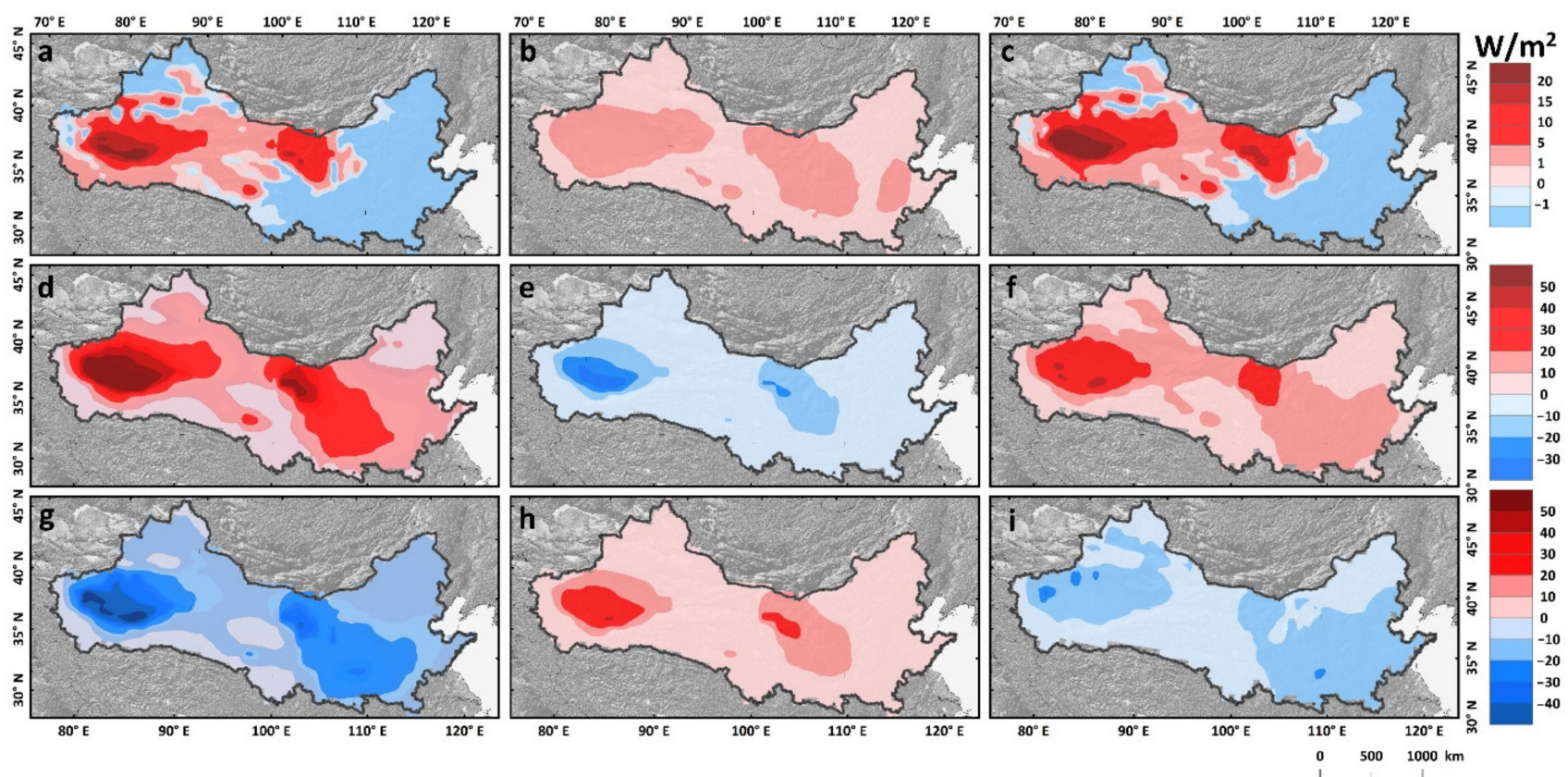

Figure A4. Average dust aerosol radiative forcing in spring. (a) Shortwave radiative forcing at the top of the atmosphere; (b) longwave radiative forcing at the top of the atmosphere; (c) net radiative forcing at the top of the atmosphere; (d) shortwave radiative forcing in the atmosphere; (e) longwave radiative forcing in the atmosphere; (f) atmospheric net radiative forcing; (g) surface shortwave radiative forcing; (h) surface longwave radiative forcing; (i) surface net radiative forcing. 
Table A1. Average dust aerosol radiative forcing in spring.

\begin{tabular}{cccc}
\hline & $\begin{array}{c}\text { Shortwave Radiative Forcing } \\
\left(\mathbf{W} / \mathbf{m}^{\mathbf{2}} \cdot \mathbf{a}\right)\end{array}$ & $\begin{array}{c}\text { Longwave Radiative Forcing } \\
\left(\mathbf{W} / \mathbf{m}^{\mathbf{2}} \cdot \mathbf{a}\right)\end{array}$ & $\begin{array}{c}\text { Net Radiative Forcing } \\
\left(\mathbf{W} / \mathbf{m}^{\mathbf{2}} \cdot \mathbf{a}\right)\end{array}$ \\
\hline Atmospheric top & 0.974 & 1.069 & 2.043 \\
Atmospheric & 18.742 & -6.334 & 12.408 \\
Surface & -17.768 & 7.403 & -10.365 \\
\hline
\end{tabular}
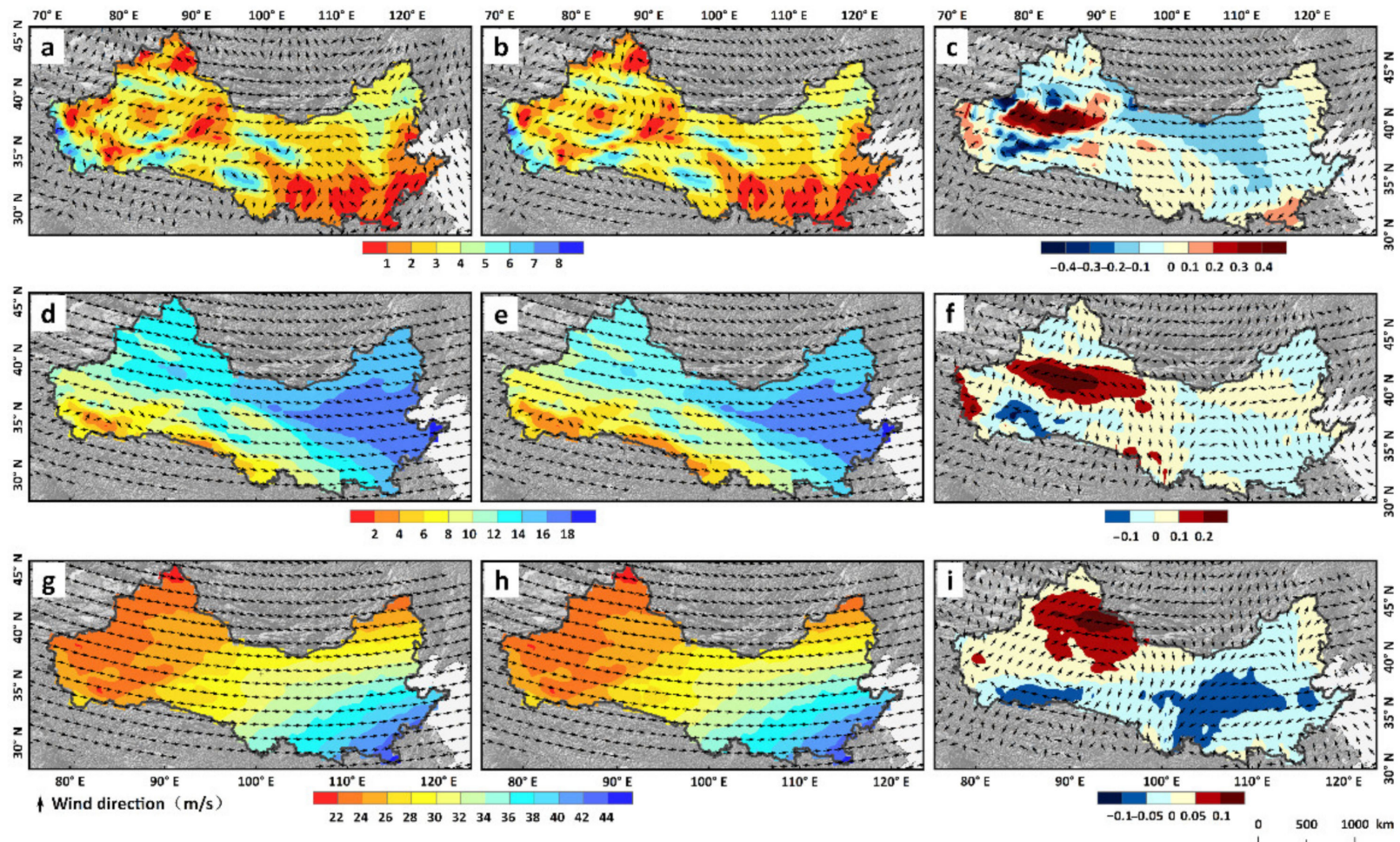

Figure A5. Circulation changes in spring under the influence of sand and dust: (a) Spring-averaged circulation at $1000 \mathrm{hPa}$ isobaric surface with the influence of sand and dust; (b) Spring-averaged circulation at $1000 \mathrm{hPa}$ isobaric surface without the influence of sand and dust; (c) Spring differential circulation at $1000 \mathrm{hPa}$ isobar caused by sand and dust; (d) Springaveraged circulation at $500 \mathrm{hPa}$ isobaric surface with the influence of sand and dust; (e) Spring-averaged circulation at $500 \mathrm{hPa}$ isobaric surface without the influence of sand and dust; (f) Spring differential circulation at $500 \mathrm{hPa}$ isobar caused by sand and dust; (g) Spring-averaged circulation at the $200 \mathrm{hPa}$ isobaric surface with the influence of sand and dust; (h) Spring-averaged circulation at the $200 \mathrm{hPa}$ isobaric surface without the influence of sand and dust; (i) Spring differential circulation at $200 \mathrm{hPa}$ isobaric surface caused by sand and dust.

\section{References}

1. Shinn, E.A.; Smith, G.W.; Prospero, J.M.; Betzer, P.; Hayes, M.L.; Garrison, V.; Barber, R.T. African dust and the demise of Caribbean coral reefs. Geophys. Res. Lett. 2000, 27, 3029-3032. [CrossRef]

2. Goudie, A.S.; Middleton, N.J. Desert Dust in the Global System; Springer Science \& Business Media: Berlin/Heidelberg, Germany, 2006.

3. Yu, H.; Chin, M.; Yuan, T.; Bian, H.; Remer, L.A.; Prospero, J.M.; Omar, A.; Winker, D.; Yang, Y.; Zhang, Y. The fertilizing role of African dust in the Amazon rainforest: A first multiyear assessment based on data from Cloud-Aerosol Lidar and Infrared Pathfinder Satellite Observations. Geophys. Res. Lett. 2015, 42, 1984-1991. [CrossRef]

4. Twohy, C.H.; Kreidenweis, S.M.; Eidhammer, T.; Browell, E.V.; Heymsfield, A.J.; Bansemer, A.R.; Anderson, B.E.; Chen, G.; Ismail, S.; DeMott, P.J. Saharan dust particles nucleate droplets in eastern Atlantic clouds. Geophys. Res. Lett. 2009, 36. [CrossRef]

5. Harrison, S.P.; Kohfeld, K.E.; Roelandt, C.; Claquin, T. The role of dust in climate changes today, at the last glacial maximum and in the future. Earth-Sci. Rev. 2001, 54, 43-80. [CrossRef]

6. Evan, A.T.; Dunion, J.; Foley, J.A.; Heidinger, A.K.; Velden, C.S. New evidence for a relationship between Atlantic tropical cyclone activity and African dust outbreaks. Geophys. Res. Lett. 2006, 33. [CrossRef] 
7. Choobari, O.A.; Zawar-Reza, P.; Sturman, A. The global distribution of mineral dust and its impacts on the climate system: A review. Atmos. Res. 2014, 138, 152-165. [CrossRef]

8. Bryant, R.G.; Bigg, G.R.; Mahowald, N.M.; Eckardt, F.D.; Ross, S.G. Dust emission response to climate in southern Africa. J. Geophys. Res. Atmos. 2007, 112. [CrossRef]

9. Kok, J.F.; Ward, D.S.; Mahowald, N.M.; Evan, A.T. Global and regional importance of the direct dust-climate feedback. Nat. Commun. 2018, 9, 1-11. [CrossRef] [PubMed]

10. Solomon, S.; Qin, D.; Manning, M.; Chen, Z.; Marquis, M.; Averyt, K.; Tignor, M.; Miller, H. Climate Change 2007: The Physical Science Basis; Intergovernmental Panel on Climate Change (IPCC), Cambridge University Press: Cambridge, UK, 2007.

11. Stocker, T.; Qin, D.; Plattner, G.; Tignor, M.; Allen, S.; Boschung, J.; Nauels, A.; Xia, Y.; Bex, V.; Midgley, P. IPCC, 2013: Summary for Policymakers in Climate Change 2013: The Physical Science Basis, Contribution of Working Group I to the Fifth Assessment Report of the Intergovernmental Panel on Climate Change; Cambridge University Press: Cambridge, UK; New York, NY, USA, 2013.

12. Shepherd, G.; Terradellas, E.; Baklanov, A.; Kang, U.; Sprigg, W.; Nickovic, S.; Boloorani, A.D.; Al-Dousari, A.; Basart, S.; Benedetti, A. Global Assessment of Sand and Dust Storms; The United Nations Environment Programme (UNEP): Nairobi, Kenya, 2016.

13. Evan, A.T.; Flamant, C.; Gaetani, M.; Guichard, F. The past, present and future of African dust. Nature 2016, 531, 493-495. [CrossRef] [PubMed]

14. Zinta, Z.; George, C.V.; Dale, S.R.; Walter, R.; Trilok, S.P.; Diego, M.; Clever, M.; Marc, A.L.; Marcel, T.K.; Peter, N.K. Blobal Environment Outlook Geo 4 Environment for Development; United Nations Environment Programme (UNEP): Nairobi, Kenya, 2007.

15. Zhang, X.; Zhao, L.; Tong, D.Q.; Wu, G.; Dan, M.; Teng, B. A systematic review of global desert dust and associated human health effects. Atmosphere 2016, 7, 158. [CrossRef]

16. Stein, S. Coping with the 'World's Biggest Dust Bowl'. Towards a History of China's Forest Shelterbelts, 1950s-Present. Glob. Environ. 2015, 8, 320-348. [CrossRef]

17. Zutz, A. Fear of the 'Steppes': Soil Protection and Landscape Planning in Germany 1930-1960 between Politics and Science. Glob. Environ. 2015, 8, 380-409. [CrossRef]

18. Sauter, S. Lessons from the US: Australia's Response to Wind Erosion (1935-1945). Glob. Environ. 2015, 8, 293-319. [CrossRef]

19. Elie, M. The Soviet Dust Bowl and the Canadian Erosion Experience in the New Lands of Kazakhstan, 1950s-1960s. Glob. Environ. 2015, 8, 259-292. [CrossRef]

20. Liu, J.; Li, S.; Ouyang, Z.; Tam, C.; Chen, X. Ecological and socioeconomic effects of China's policies for ecosystem services. Proc. Natl. Acad. Sci. USA 2008, 105, 9477-9482. [CrossRef] [PubMed]

21. Zhang, Y.; Peng, C.; Li, W.; Tian, L.; Zhu, Q.; Chen, H.; Fang, X.; Zhang, G.; Liu, G.; Mu, X. Multiple afforestation programs accelerate the greenness in the 'Three North'region of China from 1982 to 2013. Ecol. Indic. 2016, 61, 404-412. [CrossRef]

22. Chen, C.; Park, T.; Wang, X.; Piao, S.; Xu, B.; Chaturvedi, R.K.; Fuchs, R.; Brovkin, V.; Ciais, P.; Fensholt, R. China and India lead in greening of the world through land-use management. Nat. Sustain. 2019, 2, 122-129. [CrossRef]

23. Zhou, C.; Fu, B.; Wang, X.; Yin, L.; Feng, X. The Regional Impact of Ecological Restoration in the Arid Steppe on Dust Reduction over the Metropolitan Area in Northeastern China. Environ. Sci. Technol. 2020, 54, 7775-7786. [CrossRef] [PubMed]

24. Peng, S.-S.; Piao, S.; Zeng, Z.; Ciais, P.; Zhou, L.; Li, L.Z.; Myneni, R.B.; Yin, Y.; Zeng, H. Afforestation in China cools local land surface temperature. Proc. Natl. Acad. Sci. USA 2014, 111, 2915-2919. [CrossRef] [PubMed]

25. Shen, M.; Piao, S.; Jeong, S.-J.; Zhou, L.; Zeng, Z.; Ciais, P.; Chen, D.; Huang, M.; Jin, C.-S.; Li, L.Z. Evaporative cooling over the Tibetan Plateau induced by vegetation growth. Proc. Natl. Acad. Sci. USA 2015, 112, 9299-9304. [CrossRef] [PubMed]

26. Swann, A.L.; Fung, I.Y.; Chiang, J.C. Mid-latitude afforestation shifts general circulation and tropical precipitation. Proc. Natl. Acad. Sci. USA 2012, 109, 712-716. [CrossRef] [PubMed]

27. Yosef, G.; Walko, R.; Avisar, R.; Tatarinov, F.; Rotenberg, E.; Yakir, D. Large-scale semi-arid afforestation can enhance precipitation and carbon sequestration potential. Sci. Rep. 2018, 8, 1-10. [CrossRef]

28. Laguë, M.M.; Swann, A.L. Progressive midlatitude afforestation: Impacts on clouds, global energy transport, and precipitation. J. Clim. 2016, 29, 5561-5573. [CrossRef]

29. Zeng, Z.; Piao, S.; Li, L.Z.; Wang, T.; Ciais, P.; Lian, X.; Yang, Y.; Mao, J.; Shi, X.; Myneni, R.B. Impact of Earth greening on the terrestrial water cycle. J. Clim. 2018, 31, 2633-2650. [CrossRef]

30. Guan, Q.; Sun, X.; Yang, J.; Pan, B.; Zhao, S.; Wang, L. Dust storms in northern China: Long-term spatiotemporal characteristics and climate controls. J. Clim. 2017, 30, 6683-6700. [CrossRef]

31. Zhao, Y.; Xin, Z.; Ding, G. Spatiotemporal variation in the occurrence of sand-dust events and its influencing factors in the Beijing-Tianjin Sand Source Region, China, 1982-2013. Reg. Environ. Chang. 2018, 18, 2433-2444. [CrossRef]

32. Jiang, B.; Liang, S.; Yuan, W. Observational evidence for impacts of vegetation change on local surface climate over northern China using the Granger causality test. J. Geophys. Res. Biogeosci. 2015, 120, 1-12. [CrossRef]

33. Song, H.; Zhang, K.; Piao, S.; Wan, S. Spatial and temporal variations of spring dust emissions in northern China over the last 30 years. Atmos. Environ. 2016, 126, 117-127. [CrossRef]

34. Tan, M.; Li, X. Does the Green Great Wall effectively decrease dust storm intensity in China? A study based on NOAA NDVI and weather station data. Land Use Policy 2015, 43, 42-47. [CrossRef]

35. Zhao, W.; Hu, G.; Zhang, Z.; He, Z. Shielding effect of oasis-protection systems composed of various forms of wind break on sand fixation in an arid region: A case study in the Hexi Corridor, northwest China. Ecol. Eng. 2008, 33, 119-125. [CrossRef] 
36. Li, F.-R.; Zhang, H.; Zhao, L.-Y.; Shirato, Y.; Wang, X.-Z. Pedoecological effects of a sand-fixing poplar (Populus simonii Carr.) forest in a desertified sandy land of Inner Mongolia, China. Plant Soil 2003, 256, 431-442. [CrossRef]

37. Zhan, K.; Liu, S.; Yang, Z.; Fang, E.; Zhou, L.; Huang, N. Effects of sand-fixing and windbreak forests on wind flow: A synthesis of results from field experiments and numerical simulations. J. Arid Land 2017, 9, 1-12. [CrossRef]

38. Skidmore, E. Wind erosion control. Clim. Chang. 1986, 9, 209-218. [CrossRef]

39. Wu, Z.; Wu, J.; He, B.; Liu, J.; Wang, Q.; Zhang, H.; Liu, Y. Drought offset ecological restoration program-induced increase in vegetation activity in the Beijing-Tianjin Sand Source Region, China. Environ. Sci. Technol. 2014, 48, 12108-12117. [CrossRef] [PubMed]

40. Fan, B.; Guo, L.; Li, N.; Chen, J.; Lin, H.; Zhang, X.; Shen, M.; Rao, Y.; Wang, C.; Ma, L. Earlier vegetation green-up has reduced spring dust storms. Sci. Rep. 2014, 4, 6749. [CrossRef]

41. Zhang, X.Y.; Arimoto, R.; An, Z.S. Dust emission from Chinese desert sources linked to variations in atmospheric circulation. J. Geophys. Res. Atmos. 1997, 102, 28041-28047. [CrossRef]

42. Zhang, X.-Y.; Gong, S.; Zhao, T.; Arimoto, R.; Wang, Y.; Zhou, Z. Sources of Asian dust and role of climate change versus desertification in Asian dust emission. Geophys. Res. Lett. 2003, 30. [CrossRef]

43. Kok, J.F.; Adebiyi, A.A.; Albani, S.; Balkanski, Y.; Checa-Garcia, R.; Chin, M.; Colarco, P.R.; Hamilton, D.S.; Huang, Y.; Ito, A. Contribution of the world's main dust source regions to the global cycle of desert dust. Atmos. Chem. Phys. Discuss. 2021, 1-34. [CrossRef]

44. Wang, X.; Cheng, H.; Che, H.; Sun, J.; Lu, H.; Qiang, M.; Hua, T.; Zhu, B.; Li, H.; Ma, W. Modern dust aerosol availability in northwestern China. Sci. Rep. 2017, 7, 8741. [CrossRef] [PubMed]

45. Chen, S.; Huang, J.; Li, J.; Jia, R.; Jiang, N.; Kang, L.; Ma, X.; Xie, T. Comparison of dust emissions, transport, and deposition between the Taklimakan Desert and Gobi Desert from 2007 to 2011. Sci. China Earth Sci. 2017, 60, 1338-1355. [CrossRef]

46. Qian, Y.; Giorgi, F.; Huang, Y.; Chameides, W.; Luo, C. Regional simulation of anthropogenic sulfur over East Asia and its sensitivity to model parameters. Tellus B Chem. Phys. Meteorol. 2001, 53, 171-191. [CrossRef]

47. Sun, H.; Pan, Z.; Liu, X. Numerical simulation of spatial-temporal distribution of dust aerosol and its direct radiative effects on East Asian climate. J. Geophys. Res. Atmos. 2012, 117. [CrossRef]

48. Gao, X.; Giorgi, F. Use of the RegCM system over East Asia: Review and perspectives. Engineering 2017, 3, 766-772. [CrossRef]

49. Grell, G.A.; Dudhia, J.; Stauffer, D.R. A Description of the Fifth-Generation Penn State/NCAR Mesoscale Model (MM5); (No. NCAR/TN398+STR); University Corporation for Atmospheric Research: Boulder, CO, USA, 1994. [CrossRef]

50. Hirakuchi, H.; Giorgi, F. Multiyear present-day and $2 \times \mathrm{CO} 2$ simulations of monsoon climate over eastern Asia and Japan with a regional climate model nested in a general circulation model. J. Geophys. Res. Atmos. 1995, 100, 21105-21125. [CrossRef]

51. Liu, Y.; Giorgi, F.; Washington, W.M. Simulation of summer monsoon climate over East Asia with an NCAR regional climate model. Mon. Weather Rev. 1994, 122, 2331-2348. [CrossRef]

52. Solmon, F.; Giorgi, F.; Liousse, C. Aerosol modelling for regional climate studies: Application to anthropogenic particles and evaluation over a European/African domain. Tellus B Chem. Phys. Meteorol. 2006, 58, 51-72. [CrossRef]

53. Zakey, A.; Solmon, F.; Giorgi, F. Implementation and testing of a desert dust module in a regional climate model. Atmos. Chem. Phys. 2006, 6, 4687-4704. [CrossRef]

54. Marticorena, B.; Bergametti, G. Modeling the atmospheric dust cycle: 1. Design of a soil-derived dust emission scheme. J. Geophys. Res. Atmos. 1995, 100, 16415-16430. [CrossRef]

55. Alfaro, S.C.; Gomes, L. Modeling mineral aerosol production by wind erosion: Emission intensities and aerosol size distributions in source areas. J. Geophys. Res. Atmos. 2001, 106, 18075-18084. [CrossRef]

56. Zhang, D.; Zakey, A.; Gao, X.; Giorgi, F.; Solmon, F. Simulation of dust aerosol and its regional feedbacks over East Asia using a regional climate model. Atmos. Chem. Phys. 2009, 9, 1095-1110. [CrossRef]

57. Giorgi, F.; Chameides, W.L. Rainout lifetimes of highly soluble aerosols and gases as inferred from simulations with a general circulation model. J. Geophys. Res. Atmos. 1986, 91, 14367-14376. [CrossRef]

58. Giorgi, F. Two-dimensional simulations of possible mesoscale effects of nuclear war fires: 1. Model description. J. Geophys. Res. Atmos. 1989, 94, 1127-1144. [CrossRef]

59. Berrisford, P.; Dee, D.; Poli, P.; Brugge, R.; Fielding, K.; Fuentes, M.; Kallberg, P.; Kobayashi, S.; Uppala, S.; Simmons, A. The ERA-Interim Archive, Version 2.0; ECMWF: Reading, UK, 2011.

60. Balsamo, G.; Albergel, C.; Beljaars, A.; Boussetta, S.; Brun, E.; Cloke, H.; Dee, D.; Dutra, E.; Muñoz-Sabater, J.; Pappenberger, F. ERA-Interim/Land: A global land surface reanalysis data set. Hydrol. Earth Syst. Sci. 2015, 19, 389-407. [CrossRef]

61. Dee, D.P.; Uppala, S.M.; Simmons, A.; Berrisford, P.; Poli, P.; Kobayashi, S.; Andrae, U.; Balmaseda, M.; Balsamo, G.; Bauer, D.P. The ERA-Interim reanalysis: Configuration and performance of the data assimilation system. Q. J. R. Meteorol. Soc. 2011, 137, 553-597. [CrossRef]

62. Uppala, S.; Dee, D.; Kobayashi, S.; Berrisford, P.; Simmons, A. Towards a climate data assimilation system: Status update of ERA-Interim. ECMWF Newsl. 2008, 115, 12-18.

63. Su, X.-T.; Wang, H.-J.; Xu, L.-R.; Zhang, Z.-B.; Sun, H.-Y. Impact of desert dust on the East Asian summer monsoon. J. Trop. Meteorol. 2016, 22, 252.

64. Zhang, J.; Zhao, T.; Jiang, C.; Cao, S. Opportunity cost of water allocation to afforestation rather than conservation of natural vegetation in China. Land Use Policy 2016, 50, 67-73. [CrossRef] 
65. Zhou, Y.; Chang, X.; Ye, S.; Zheng, Z.; Lv, S. Analysis on regional vegetation changes in dust and sandstorms source area: A case study of Naiman Banner in the Horqin sandy region of Northern China. Environ. Earth Sci. 2015, 73, 2013-2025. [CrossRef]

66. Long, X.; Tie, X.; Li, G.; Cao, J.; Feng, T.; Zhao, S.; Xing, L.; An, Z. Effect of ecological restoration programs on dust concentrations in the North China Plain: A case study. Atmos. Chem. Phys. 2018, 18, 6353-6366. [CrossRef]

67. Wei, W.; Wang, B.; Niu, X. Soil Erosion Reduction by Grain for Green Project in Desertification Areas of Northern China. Forests 2020, 11, 473. [CrossRef]

68. Miller, R.L.; Knippertz, P.; García-Pando, C.P.; Perlwitz, J.P.; Tegen, I. Impact of Dust Radiative Forcing upon Climate. In Mineral Dust; Springer: Berlin/Heidelberg, Germany, 2014; pp. 327-357.

69. Woodward, S.; Roberts, D.; Betts, R. A simulation of the effect of climate change-induced desertification on mineral dust aerosol. Geophys. Res. Lett. 2005, 32. [CrossRef]

70. Mahowald, N.M. Anthropocene changes in desert area: Sensitivity to climate model predictions. Geophys. Res. Lett. 2007, 34. [CrossRef]

71. Tegen, I.; Werner, M.; Harrison, S.; Kohfeld, K. Relative importance of climate and land use in determining present and future global soil dust emission. Geophys. Res. Lett. 2004, 31. [CrossRef]

72. Yao, T.; Masson-Delmotte, V.; Gao, J.; Yu, W.; Yang, X.; Risi, C.; Sturm, C.; Werner, M.; Zhao, H.; He, Y. A review of climatic controls on $\delta 18 \mathrm{O}$ in precipitation over the Tibetan Plateau: Observations and simulations. Rev. Geophys. 2013, 51, 525-548. [CrossRef]

73. DeMott, P.J.; Prenni, A.J.; Liu, X.; Kreidenweis, S.M.; Petters, M.D.; Twohy, C.H.; Richardson, M.; Eidhammer, T.; Rogers, D. Predicting global atmospheric ice nuclei distributions and their impacts on climate. Proc. Natl. Acad. Sci. USA 2010, 107, 11217-11222. [CrossRef] [PubMed]

74. Sagoo, N.; Storelvmo, T. Testing the sensitivity of past climates to the indirect effects of dust. Geophys. Res. Lett. 2017, 44, 5807-5817. [CrossRef]

75. Bullard, J.E.; Baddock, M.; Bradwell, T.; Crusius, J.; Darlington, E.; Gaiero, D.; Gasso, S.; Gisladottir, G.; Hodgkins, R.; McCulloch, R. High-latitude dust in the Earth system. Rev. Geophys. 2016, 54, 447-485. [CrossRef]

76. Feng, X.; Fu, B.; Piao, S.; Wang, S.; Ciais, P.; Zeng, Z.; Lü, Y.; Zeng, Y.; Li, Y.; Jiang, X. Revegetation in China's Loess Plateau is approaching sustainable water resource limits. Nat. Clim. Chang. 2016, 6, 1019-1022. [CrossRef]

77. Brandt, M.; Rasmussen, K.; Hiernaux, P.; Herrmann, S.; Tucker, C.J.; Tong, X.; Tian, F.; Mertz, O.; Kergoat, L.; Mbow, C. Reduction of tree cover in West African woodlands and promotion in semi-arid farmlands. Nat. Geosci. 2018, 11, 328-333. [CrossRef]

78. Song, X.-P.; Hansen, M.C.; Stehman, S.V.; Potapov, P.V.; Tyukavina, A.; Vermote, E.F.; Townshend, J.R. Global land change from 1982 to 2016. Nature 2018, 560, 639-643. [CrossRef] [PubMed]

79. Ginoux, P.; Chin, M.; Tegen, I.; Prospero, J.M.; Holben, B.; Dubovik, O.; Lin, S.J. Sources and distributions of dust aerosols simulated with the GOCART model. J. Geophys. Res. Atmos. 2001, 106, 20255-20273. [CrossRef]

80. Song, Z.; Fu, D.; Zhang, X.; Wu, Y.; Xia, X.; He, J.; Han, X.; Zhang, R.; Che, H. Diurnal and seasonal variability of PM2.5 and AOD in North China plain: Comparison of MERRA-2 products and ground measurements. Atmos. Environ. 2018, 191, 70-78. [CrossRef] 